a result of a suspected early intrauterine insult show an increased frequency of abnormal creases. There is an association between interrupted transverse creases and intrauterine methadone exposure. Race, sex, age, and intrafamilial concordance are some of the variables that should be considered in evaluating palmar crease patterns.

\section{REFERENCES AND NOTES}

1. Achs, R., Harper, R. G., and Siegel, M: Unusual dermatoglyphic findings associated with rubella embryopathy. New Engl. J. Med. 274:148 (1966).

2. Alter, M.: Variation in palmar creases. Amer. J. Dis. Child., 20: 424 (1970).

3. Dar, H. Carney, F. C., and Winter, S. T.: Dermatoglyphics and the simian crease in infants of low birth weight: A pilot study. Acta Paediat. Scand, 60 : 479 (1971).

4. Dar, H., and Schmidt, R.: A topographic approach for analysis of palm crease variants. J. Med. Genet. 13:310 (1976).

5. Davies, P. A., and Smallpeice, V.: The single transverse palmar crease in infants and children. Dev. Med. Child. Neurol., 5: 491 (1963).

6. Davies, P. A., and Smallpeice, V.: Sex and the single transverse palmar crease in newborn singletons. Dev. Med. Child. Neurol., 8: 729 (1966)

7. Debrunner, I. M.: Morphologischer Bauplan der ballenbedingten Handfurchen bei Primaten. Z. Anthropol. Morphol., 47: 187 (1956).

8. Holt, S. B.: The Genetics of Dermal Ridges (Charles C Thomas, Springfield, Ill., 1968).

9. Hook, E. B., Bonenfast, R. C. A., Powers, M. L., Greenberg. M., and Shapiro, L. R.: The human simian crease and its variants-A model for investigation of serious congenital malformations. Birth Def., 10(7): 7 (1974).

10. Johnson, C. F., and Opitz, E.: Unusual palm creases and unusual children. The Sydney line and "type C". palmar lines and their clinical significance in child development clinic. Clin. Pediat., 12: 101 (1973).

11. Jones, K. L., Smith, D. W.. Ulieland, C. N., and Streissguth, A. P.: Pattern of malformation in offspring of alcoholic mothers. Lancet, 1: 1267 (1973).

12. Lubchenco, L. O., Hansman, C., and Boyd, E.: Intrauterine growth in length and head circumference as estimated from live births at gestational ages from 26 to 42 weeks. Pediatrics, 37: 403 (1966).

13. Milunsky, A., Great, J. W., and Gaynor, M. F.: Methotrexate-induced congenital malformations. J. Pediat., 72: 790 (1968).

14. Pfeiffer, R. A., and ZuBerge. U. S.: Untersuchungen zur Frage der Handleis- ten und Furchen bei Extremitaeten Missbildungen. Menchl. Venerb. Konstitutionlehre, 37: 677 (1964)

15. Plato, C. C., Cereghino, J. J., and Steinberg, F. S. Palmar dermatoglyphics of Down's syndrome. Pediat. Res., 7: 111 (1973)

16. Purvis-Smith, S. G., and Menser, M. A.: Dermatoglyphic defects and rubella teratogenesis. J. Amer. Med. Ass., 209: 1865 (1968)

17. Rosner, F., Steinberg, F. S., and Sprigge, H. A.: Dermatoglyphic patterns in patients with selected neurological disorders. Amer. J. Med. Sci., 254: 134 (1967).

18. Uchida, I. A.. Patau, K., and Smith. D. W.: Dermal patterns of 18 and $D_{1}$ trisomies. Amer. J. Hum. Genet., 14:345 (1962).

19. Van den Berg. B. J., and Yerushalmy, J.: The relationship of the rate of intrauterine growth of infants of low birth weight to mortality, and congenital anomalies. J. Pediat.. 69: 531 (1966).

20. Vrydagh-Laoureux, S.: Le pli palmaire transverse dans une population belge normale et chez 86 mongoliens. Bull. Soc. Roy. Belge Anthrop. Prehist. 78: 237 (1967)

21. Wright, H. T., Parker, C. E., and Mavalwala, J.: Unusual dermatoglyphic findings associated with cytomegalic inclusion disease of infancy. Calif. Med., 116: 19 (1972)

22. Informed consent was obtained from the mother before obtaining palm print patterns on newborn infants or older children, in accord with the procedure approved by the Committee on Clinical Investigation of the Bronx Municipal Hospital Center.

23. A signed release was obtained from the mother to permit a photograph to be obtained and published of this infant's hand, in accord with established policy at this institution.

24. We wish to thank Dr. L. M. Gartner, Dr. S. Kandall, and Mrs. M. Winters, and Miss E. Caputo and other members of the staff of the Neonatalogy Division at the Bronx Municipal Hospital Center for their cooperation. We also wish to acknowledge the assistance and cooperation of the principals and teachers of the St. Helena and Philip and James Schools, the Memorial Nursery School, and Dr. K. S. Lobach and the staff of the Comprehensive Child Care Program.

25. Submitted by H. Dar in partial fulfillment of the requirements for the Ph.D. degree at the Technion Institute of Technology. Haifa, Israel. Present address: Genetic Unit, Rothschild Hospital, Haifa, Israel.

26. Requests for reprints should be addressed to: H. M. Nitowsky. M.D. Department of Pediatrics, Albert Einstein College of Medicine, Bronx, N. Y. 10461 (USA)

27. Received for publication February 18, 1976.

28. Accepted for publication August 6, 1976 premature infants glucagon glucose small for gestational age insulin

(SGA) infants

\title{
Effects of Oral Glucose and Protein Load on Plasma Glucagon and Insulin Concentrations in Small for Gestational Age Infants
}

\author{
B. L. SALLE AND A. RUITON-UGLIENGO(31)
}

Neonatal Department, Hôpital E. Herriot, Lyon, France

\section{Summary}

This paper reports portal and peripheral blood glucose, insulin, and glucagon levels in small for gestational age (SGA) and appropriate for gestational age (A GA) newborns during the first $48 \mathrm{hr}$ of life. These parameters were studied after an oral glucose and protein load (1 $\mathrm{g} / \mathrm{kg}$ of each) after a $4-\mathrm{hr}$ fast.

In AGA and SGA infants, mean fasting blood glucose level was significantly higher in the portal vein than in the aorta $(P<$ $0.05)$. After the load, mean blood glucose level rose significantly in both vessels.
The mean fasting plasma insulin level was low and was similar in both vessels. After the load in the AGA group mean plasma insulin level rose significantly at $45 \mathrm{~min}$ in both vessels $(P<$ $0.05)(52.1 \pm 37.2 \mu \mathrm{U} / \mathrm{ml}$ in aorta and $91.8 \pm 75.3 \mu \mathrm{U} / \mathrm{ml}$ in portal vein). In the SGA group, the insulin response was minimal in the aorta and in the portal vein; the increase was significant only in the portal vein $(P<0.05)$ at $180 \mathrm{~min}(47.1 \pm 25.3$ $\boldsymbol{\mu} \mathbf{U} / \mathbf{m l})$.

The mean fasting plasma glucagon level was higher in the portal vein than in the aorta in both groups $(P<\mathbf{0 . 0 5})$. After the load in AGA infants plasma glucagon rose significantly from 
$193 \pm 55 \mathrm{pg} / \mathrm{ml}$ at zero time to $290 \pm 76.8 \mathrm{pg} / \mathrm{ml}$ at $180 \mathrm{~min}(P$ $<0.01)$ in the aorta but not in the portal vein. In the SGA group, the mean plasma glucagon did not rise significantly in the aorta or in the portal vein (from $231.2 \pm 54.3 \mathrm{pg} / \mathrm{ml}$ at zero time to $293.7 \pm 123.5 \mathrm{pg} / \mathrm{ml}$ at $180 \mathrm{~min}$ in the portal vein). The molar ratio of insulin to glucagon $(I / G)$ rose significantly after the load in the portal vein in both groups of infants (AGA 2.48 \pm 2.06 at zero time to $5.08 \pm 4.06$ at $180 \mathrm{~min}$; SGA infants from $2.2 \pm 1.98$ at zero time to $4.16 \pm 2.59$ at $180 \mathrm{~min}$ ).

When both groups of infants were compared there was no significant difference either in the aorta or in the portal vein in mean blood glucose, mean plasma level, and plasma glucagon level.

It is concluded that SGA and AGA premature infants are similar in regard to secretion of both pancreatic hormones in the first days of life.

\section{Speculation}

During an oral load of protein and glucose, the mean values of plasma insulin, glucagon, and the insulin to glucagon molar ratio in plasma of SGA infants did not differ significantly from values for control infants; this study provides evidence that in SGA infants the pancreatic endocrine activity is capable of adapting to the metabolic state at birth. It is likely that the instability of glucose metabolism in SGA infants is a consequence of the rapid disappearance rate of glucose and probably also of a transient deficiency of gluconeogenic enzymes in the liver.

Infants who are small for gestational age have a high incidence of hypoglycemia $(4,11,15)$. The reasons for this instability in carbohydrate metabolism are not fully understood, although there are many reports in the literature on the hormonal regulation of glucose metabolism in SGA infants $(16,18,25)$. We have shown previously that plasma insulin levels during hypoglycemia are identical or slightly higher in SGA infants as compared with fasting normal infants (19).

There have been recent reports of high levels of glucagon in the umbilical artery, in the umbilical vein, and in the peripheral blood of term newborn infants $(1,5,11,14,21,25)$ and of premature infants $(7,8)$. Plasma glucagon levels in both normal and premature infants increase during the first days of life. In healthy term newborn infants intravenous or oral alanine feeding raises plasma glucagon and glucose levels (25). Similarly, plasma insulin and glucagon levels increase after arginine infusion (21). Recently, Williams et al. (25) observed that in SGA infants gluconeogenic amino acids stimulate glucagon secretion without enhancing hepatic glucose output. These findings may reflect a decrease in glucogen stores and an ineffective gluconeogenetic enzymatic system in SGA infants.

This study was designed to elucidate the effect of an oral load of glucose and protein on hormonal levels in SGA infants compared with the responses observed in babies of similar weight who were appropriate for gestational age. In both groups, we studied plasma glucagon and insulin levels and the insulin to glucagon molar ratio in the portal vein and in the aorta.

\section{MATERIALS AND METHODS}

Fifteen newborn infants were studied during the first $48 \mathrm{hr}$ of life. All study procedures were approved in conformity with the ethic committee of the Unite de Recherches U.34. The infants were divided into two groups according to the gestational age. The gestational age was calculated from the first day of the last menstrual period and was also assessed clinically. The eight SGA infants had a birth weight below the 10th percentile for their gestational age according to the French intrauterine growth curves (10); the mean birth weight was $1.998 .7 \pm 136.3 \mathrm{~g}$ and the mean gestational age was $38 \pm 15$ weeks. The seven infants who were AGA had a birth weight between the 10th and the 90th percentile; in this group mean birth weight was $1,984.2 \pm$ $170 \mathrm{~g}$ and mean gestational age was $34.7 \pm 1.7$ weeks

The incidence of complicated pregnancies was similar in the two groups, except for the occurrence of twin pregnancy and toxemia in the group of SGA infants (Table 1). Infants were nursed in a thermoneutral environment with an abdominal skin temperature of $36.5^{\circ}$, using an infant Servocontrol system. The infants received breast milk from $12 \mathrm{hr}$ of age and a $10 \%$ glucose infusion was given by peripheral vein. The studies were conducted $4 \mathrm{hr}$ after the last feeding.

The lower abdominal aorta and portal vein were catheterized through the umbilical artery and the umbilical vein. The positions of the tips of the catheters were checked radiologically; catheters were removed immediately after the study. No complications ensued.

After a 4-hr fast during which the infusion was maintained by physiologic saline at a flow rate of less than $1 \mathrm{ml} / \mathrm{hr}$, each infant was fed with $1 \mathrm{~g}$ glucose and $1 \mathrm{~g}$ protein (casein, Merck)/kg in physiologic saline $(10 \mathrm{ml})$ administered by a nasogastric tube within a 5 -min period.

Blood samples $(2.5 \mathrm{ml})$ were obtained simultaneously from the portal vein and the aorta at zero time, $45 \mathrm{~min}, 120 \mathrm{~min}$, and $180 \mathrm{~min}$ into previously chilled tubes. Blood samples for glucagon determinations were collected in tubes containing EDTA and Zymofren. The tubes were rapidly centrifuged and the plasma was removed and frozen until assayed.

Plasma glucagon was determined by radioimmunoassay (17) Values for normal fasting plasma glucagon levels obtained in 20 infants of more than 2 years of age were $153 \mathrm{pg} / \mathrm{ml} \pm 27$ SEM $\mathrm{pg} / \mathrm{ml}$; in four young infants (age less than 6 months) fasting plasma glucagon levels of $173,185,163$, and $171 \mathrm{pg} / \mathrm{ml}$, respectively, were found.

Plasma glucose was measured in duplicate by the glucose oxidase method without precipitation of plasma protein (Beckman analyzer glucose). Plasma immunoreactive insulin was measured using the method of Hales and Randle (9). ${ }^{125} \mathrm{I}$ was obtained from the Radiochemical Centre, Amersham, England, with a specific activity of not less than $50 \mu \mathrm{Ci} / \mu \mathrm{g}$.

\section{CALCULATION AND STATISTICAL ANALYSIS}

For each period of time, results were expressed as mean \pm standard deviation (SD); paired test, Student $t$-tests, and regression analysis were performed. All calculations were made by submitting the data to an Iris 60 computer (27).

\section{RESULTS}

The results are presented in Figures $1-4$ and in Tables 2 and 3.

\section{GROUP OF AGA PREMATURE INFANTS}

The mean fasting blood glucose level was significantly higher in the aorta than in the portal vein $(P<0.05)$. After the oral load, the mean plasma glucose level rose in the portal vein and in the aorta at 45 and $120 \mathrm{~min}(P<0.01)$, but the difference between both vessels was not significant (Fig. 1) at any time.

The mean fasting plasma insulin levels were not different in the portal vein and in the aorta; after the glucose and the protein load, the mean plasma insulin level rose significantly at $45 \mathrm{~min}$ in

Table 1. Pregnancy complications of study subjects

\begin{tabular}{lcc}
\hline \multicolumn{1}{c}{ Complication } & $\begin{array}{c}\text { Infants appropriate for } \\
\text { gestational age }\end{array}$ & $\begin{array}{r}\text { Infants small for gesta- } \\
\text { tional age }\end{array}$ \\
\hline Cesarean section & 1 & 1 \\
Toxemia & 0 & 2 \\
Breech delivery & 1 & 1 \\
Twins & 1 & 3 \\
Uncomplicated & 4 & 1 \\
\hline
\end{tabular}




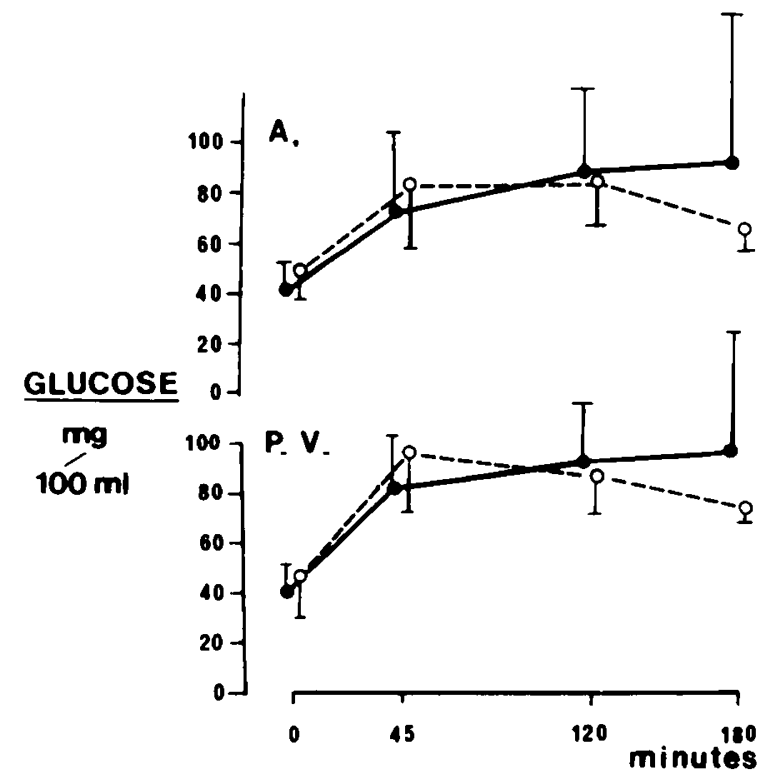

Fig. 1. Plasma glucose level (mean and SD) after oral load in aorta $(A$.$) and the portal vein (P . V$.$) . \longrightarrow$ : appropriate for gestational age infants: $O_{-}-O$ : small for gestational age infants.

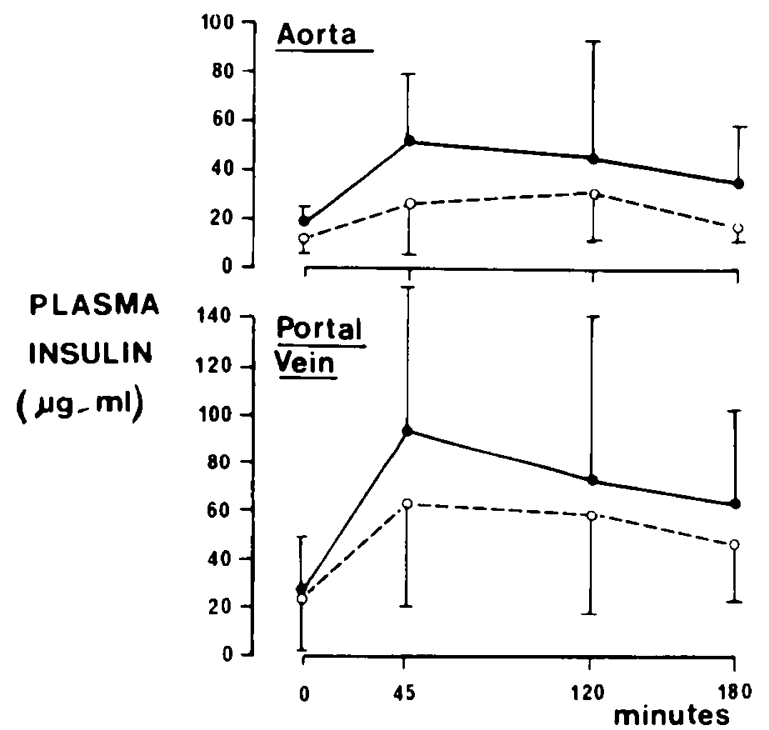

Fig. 2. Plasma insulin (mean and SD) after oral load in aorta and the portal vein. - — : appropriate for gestational age infants; $\mathrm{O}_{-} \ldots$. small for gestational age infants.

both vessels $(P<0.05)$ and then decreased at $120 \mathrm{~min}$ and 180 min. Mean plasma insulin levels were significantly higher in portal vein than in aorta at $120 \mathrm{~min}(P<0.05)$ (Fig. 2).

The mean fasting plasma glucagon level was significantly higher in the portal vein than in the aorta $(P<0.025)$. After the glucose and protein load the mean plasma glucagon level rose significantly in the aorta at $45 \mathrm{~min}(P<0.025) 120 \mathrm{~min}(P<$ $0.01)$, and $180 \mathrm{~min}(P<0.001)$, but not in the portal vein (Fig. $3)$. Mean plasma glucagon level was higher in the portal vein than in the aorta only at $120 \mathrm{~min}$ (Table 2 ).

The mean fasting molar ratio $\mathrm{l} / \mathrm{G}$ was low. After the load the ratio rose significantly only in the portal vein at $45 \mathrm{~min}(P<$ $0.01), 120 \mathrm{~min}(P<0.05)$, and $180 \mathrm{~min}(P<0.05)$.

\section{GROUP OF SGA INFANTS}

The mean fasting blood glucose level was significantly higher in the portal vein than in the aorta $(P<0.05)$. After the load the mean blood glucose level rose significantly in the portal vein and in the aorta blood; no difference was observed at any time between both vessels (Fig. 1).

There was no difference in mean fasting plasma insulin levels in the portal vein and in the aorta. After the load the mean plasma insulin level increased slightly in the aorta; in the portal

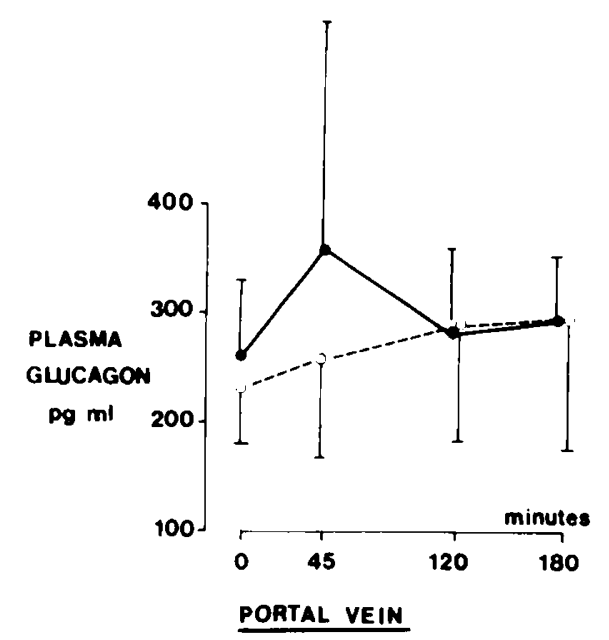

Fig. 3. Plasma glucagon in the portal vein after oral load appropriate for gestational age infants; $\bigcirc_{-}-\bigcirc$ : small for gestational age infants.

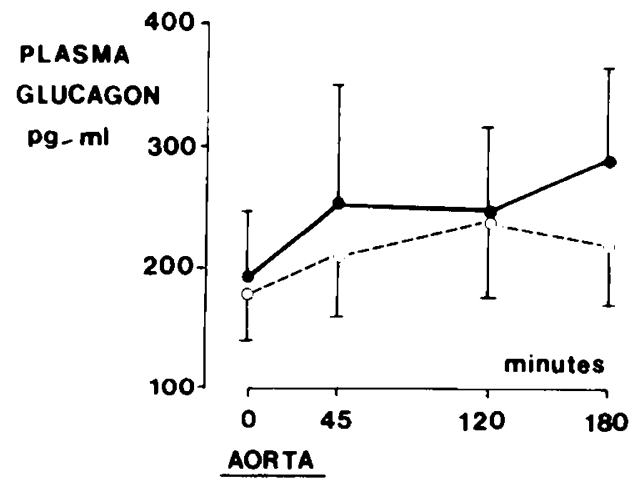

Fig. 4. Plasma glucagon in aorta after oral load. $-\longrightarrow$ : appropriate for gestational age infants; $\bigcirc---\bigcirc$ : small for gestational age infants.

Table 2. Small for gestational age infants: Mean values $( \pm I S D)$ for plasma glucose, plasma insulin (I), plasma glucagon $(G)$, and $I / G$ ratio before and after oral glucose and protein load

\begin{tabular}{lcccc}
\hline & $0 \mathrm{~min}$ & $45 \mathrm{~min}$ & $120 \mathrm{~min}$ & $180 \mathrm{~min}$ \\
\hline Glucose, $\mathrm{mg} / \mathrm{l}(00 \mathrm{ml}$ & & & & \\
Aorta & 49.12 & 83.6 & 84.8 & 66.1 \\
& \pm 11.84 & \pm 24.8 & \pm 16.1 & \pm 7.8 \\
Portal vein & 46.4 & 98.1 & 90.6 & 75.2 \\
& \pm 11.1 & \pm 26 & \pm 17.9 & \pm 7.3 \\
Insulin, $\mu \mathrm{U} / \mathrm{ml}$ & & & & \\
$\quad$ Aorta & 12.6 & 28.8 & 30.8 & 18.7 \\
& \pm 3.6 & 2 & \pm 17.5 & \pm 4.2 \\
Portal vein & 24.1 & 61 & 58.6 & 47.1 \\
& \pm 25.5 & \pm 41 & \pm 39.7 & \pm 25.3 \\
Glucagon, pg/ml & & & & \\
Aorta & 181 & 208 & 240 & 220 \\
Portal vein & \pm 38.2 & \pm 47.5 & \pm 61.6 & \pm 50.8 \\
& 231.2 & 258.7 & 288.7 & 293.7 \\
I/G ratio & \pm 54.3 & \pm 92.1 & \pm 106.3 & \pm 123.5 \\
Aorta & 1.65 & 3.15 & 3.02 & 2.04 \\
& \pm 0.6 & \pm 2.4 & \pm 1.47 & \pm 0.5 \\
Portal vein & 2.2 & 5.37 & 5.02 & 4.16 \\
& \pm 1.98 & \pm 3.7 & \pm 3.47 & \pm 2.59 \\
\hline
\end{tabular}


Table 3. Appropriate for gestational age infants: Mean values $( \pm I S D)$ for plasma glucose, plasma insulin (I), plasma glucagon $(G)$, and $I / G$ ratio before and after oral glucose and protein load

\begin{tabular}{lcccc} 
& $0 \mathrm{~min}$ & $45 \mathrm{~min}$ & $120 \mathrm{~min}$ & $180 \mathrm{~min}$ \\
\hline Glucose, $\mathrm{mg} / 100 \mathrm{ml}$ & & & & \\
Aorta & 40.14 & 76.33 & 88.7 & 93.1 \\
& \pm 10.37 & \pm 28.5 & \pm 34 & \pm 60.9 \\
Portal vein & 42.8 & 82 & 91.4 & 99.5 \\
& \pm 9.6 & \pm 22.5 & \pm 30 & \pm 65.3 \\
Insulin. $\mu \mathrm{U} / \mathrm{ml}$ & & & & \\
Aorta & 17.4 & 52.1 & 46.5 & 36.7 \\
& \pm 7.9 & \pm 37.2 & \pm 47.3 & \pm 24.3 \\
Portal vein & 27.3 & 91.8 & 71.7 & 61 \\
& \pm 21.9 & \pm 75.3 & \pm 70.8 & \pm 45.2 \\
Glucagon, pg/mI & & & & \\
Aorta & 193 & 251.8 & 247.1 & 290 \\
& \pm 55.3 & \pm 88.3 & \pm 67 & \pm 76.8 \\
Portal vein & 264 & 350.2 & 286.4 & 298.6 \\
& \pm 73.5 & \pm 230.2 & \pm 82.2 & \pm 61 \\
I/G ratio & & & & \\
Aorta & 2.15 & 4.91 & 4.17 & 3.79 \\
& \pm 0.95 & \pm 3.63 & \pm 3.29 & \pm 3.60 \\
Portal vein & 2.48 & 5.97 & 5.59 & 5.08 \\
& \pm 2.06 & \pm 3.89 & \pm 4.35 & \pm 4.26 \\
\hline
\end{tabular}

vein the increase was only significant at $180 \mathrm{~min}(P<0.05)$. Two SGA infants did not show any increase in plasma insulin either in the aorta or in the portal vein. The mean plasma insulin level was significantly higher in the portal vein than in the aorta at $45 \mathrm{~min}(P<0.005), 120 \mathrm{~min}(P<0.05)$, and $180 \mathrm{~min}(P<$ ().01) (Table 3).

The mean fasting plasma glucagon level was significantly higher in the portal vein than in the aorta $(P<0.05)$. No significant changes were observed in mean plasma glucagon level after the load in both vessels (Table 3 ).

The mean molar ratio $\mathrm{I} / \mathrm{G}$ rose significantly after the load only in the portal vein from $2.2 \pm 1.98$ to $4.16 \pm 2.59$ at $180 \mathrm{~min}(P$ $<0.0(01)$.

\section{CORRELATION ANALYSIS}

There was no correlation between plasma insulin and plasma glucagon levels and gestational age at any period of time in both groups. In the group of AGA infants, a positive correlation was found between fasting plasma glucagon levels in the aorta and the postnatal age of the infant $(r=0.58 ; P<0.01)$. In the group of SGA infants, a positive correlation was found between fasting plasma glucagon levels in the portal vein and the postnatal age of the infant $(r=0.55 ; P<0.05)$.

\section{COMPARISON OF TWO GROUPS}

No difference was found between the two groups in mean blood glucose, plasma glucagon levels, plasma insulin levels, and mean molar ratio $\mathrm{I} / \mathrm{G}$ at any time either in aorta or in portal vein.

\section{DISCUSSION}

We have studied the equilibrium of both pancreatic hormones after a physiologic stimulation in normal conditions in AGA and SGA newborns during the first 2 days of life.

In the well nourished adult, the ingestion of protein elicits a rise in insulin and a relatively parallel, although proportionately smaller, rise in glucagon which serves to prevent aminogenic hypoglyeemia $(6,22)$; however, if carbohydrate is ingested together with the protein, the insulin to glucagon molar ratio rises as a conseyuence of an exaggerated rise in insulin secretion (5, 20. 23). In fact, the insulin to glucagon molar ratio is assumed to be the index of the endocrine pancreatic control of glucose metabolism in the liver $(22,23)$.

In the newborn period, with concomitant interruption of the maternal nutrient supply. glucose is provided by glycogenol- ysis and increased gluconeogenesis, until the newborn or premature infant can receive a normal caloric intake.

Our data confirm previous reports that the pancreatic glucagon secretion mechanism is functional in low birth weight newborns (premature and SGA) $(5,7,12,21)$.

The blood glucagon concentration during fasting is similar to that of normal children (17) for both AGA and SGA groups; we have demonstrated that it correlates with the postnatal age of the infant. After the oral load, there is a comparable increase of plasma insulin in both vessels for both groups, showing that SGA infants are able to respond comparably to the AGA infants. There is a slight but insignificant increase of plasma glucagon in the SGA group.

Sampling simultaneously from the portal vein and aorta permits study of the concentration of insulin and glucagon resulting from secretion by the pancreas. We have previously reported the difference in insulin concentration between these vessels in small premature as well as in SGA infants after an intravenous load of glucose (19). We report a significant difference in the insulin response between aorta and portal vein; insulin levels are higher in the portal vein, suggesting storage or degradation by the liver. The plasma glucagon was higher in the portal vein only at 120 min in the SGA group.

The uptake or degradation of pancreatic glucagon in the liver seems to be less because the glucagon levels are higher in the portal vein than in the aorta; thus confirming a portoperipheral gradient from plasma glucagon as demonstrated in man under physiologic conditions (3). This gradient is minimal after an overnight fast but increases markedly after a stimulus such as arginine infusion. After a meal, the fluctuations may be significant in pancreatic or portal blood but slight in peripheral blood (3).

The insulin to glucagon molar ratio must be taken into consideration when interpreting such findings. During fasting, the high levels of glucagon and the low value of the $1 / G$ ratio in the portal vein in both groups suggests that the necessary glucose is produced by glucogenolysis and gluconeogenesis. The mean value of the $\mathrm{I} / \mathrm{G}$ ratio in AGA infants $(2.48 \pm 206)$ and in SGA infants $(2.2 \pm 2.98)$ is similar to that found in fasting children $(17,22$. $24)$. After the protein and glucose meal, the $I / G$ ratio increases and reaches a peak at $45 \mathrm{~min}$, which is, however, lower than that reported in children or in normal adults after feeding (22). The decrease of the ratio at 60 and 120 min is related to a progressive decrease of insulin levels and a constant increase of glucagon levels in both groups. We did not find any difference between SGA and AGA infants; therefore, the malnourished SGA infants can apparently adapt the bihormonal function to the metabolic state as well as the AGA infants.

Anthony and Faloona (2) measured the plasma concentration of insulin and glucagon in a rat model for protein malnutrition; they found reduced plasma insulin levels, although plasma glucagon levels were comparable to adequately fed, age-matched control subjects.

Therefore, the low blood sugar in SGA infants is not explained by a deficient secretion of pancreatic hormones. It is more likely a consequence of the rapid disappearance rate of glucose that we have demonst rated previously $(18.19)$, which is presumably dependent on the high glucose requirement of the relative large neonatal brain. There also remains the possibility that a lower liver glycogen reserve and/or a transient deficiency of gluconeogenic enzymes is the cause (26).

\section{CONCLUSION}

The effect of oral glucose and protein stimulation on the portal and peripheral blood sugar, plasma insulin, and plasma glucagon was studied in eight small for gestational age newborns and seven appropriate for gestational age premature infants during the first $48 \mathrm{hr}$ of life.

In the premature infants insulin and glueagon concentration increased significantly, but in the SGA infants the response of both hormones was minimal. However, no difference in the 
response was found between the two groups. The $\mathrm{I} / \mathrm{G}$ molar ratio, low during fasting, rose significantly after stimulation in both groups.

We have demonstrated that pancreatic endocrine activity is the same at birth in both SGA and AGA infants and is adequate to the metabolic state in neonatal life.

\section{REFERENCES AND NOTES}

1. Adams, P. A. J.: Control of glucose metabolism in the human fetus and the newborn infant. Advan. Metabol. Disord.. 5: 184 (1971).

2. Anthony, L. E., and Faloona, G. R.: Plasma insulin and glucagon levels in protein malnourished rats. Metabolism, 23: 303 (1974).

3. Assan, R.: In vivo metabolism of glucagon. In: P. J. Lefebvre and R. H. Unger: Glucagon, Vol. 47 (Pergamon Press, New York, 1972).

4. Cornblath, M., Wybregt, S.'H., Baens, G. S., and Klein, R. I.: Symptomatic neonatal hypoglycemia: Studies of carbohydrate metabolism in the newborn infants. Pediatrics, 33: 388 (1964).

5. Delamater, P. V., Sperling, M. A., Fiser R. M., Phelps D. L., Oh, W., and Fischer D. A.: Plasma alanine relation to plasma glucose, glucagon and insulin in the neonate. J. Pediat., 85: 702 (1974).

6. Exton, J. M.: Gluconeogenesis. Metabolism, 21: 945 (1972)

7. Falorni, A., Massi-Benedetti, F., Gallo, S., and Romizi. S.: Levels of glucose in blood and insulin in plasma and glucagon response to arginine infusion in low birth weight infants. Pediat. Res.. 9: 55 (1975).

8. Falorni, A.. Massi-Benedetti, F., Gallo, S., and Trabalza, N.: Blood glucose. serum insulin, and glucagon response to arginine in premature infants. Biol. Neonate, 27: 271 (1975)

9. Hales, C. N., and Randle, P. J.: Immunoassay of insulin with insulin antibody precipitate. Biochem. J., 88: 137 (1963).

10. Leroy, B., and Lefort, F.: Courbes de croissance du nouveau-né et du prématuré Rev. Franç. Gynecol., 66: 391 (1971).

11. Lubchenko, L. O.. and Bard, H.: Incidence of hypoglycemia in newborn infants classified by birth weight an gestational age. Pediatrics, 47: 831 (1971).

12. Luyck, A. S., Massi-Benedetti, F., Falorni, A., and Lefebvre, P. J.: Presence of pancreatic glucagon in the portal plasma of human neonates: Differences of insulin and glucagon response to glucose between normal infants and infants of diabetic mothers. Diabetologia, 8: 296 (1972).

13. Massi-Benedetti, F., Falorni, A., Luyck, A., and Lefebvre, P. J.: Inhibition of glucagon secretion in the human newborns by simultaneous administration of glucose insulin. Hormone Metabol. Res., 6: 392 (1974).

14. Milner, R. D. G., Chouksey, S. K.. Micklesow, K. N. P., and Assan, R.: Plasma pancreatic glucagon and insulin glucagon ratio at birth. Arch. Dis. Childhood, 49: 241 (1973).

Copyright (c) 1977 International Pediatric Research Foundation, Inc.
15. Neligan, G. A., Robson, E., and Watson. J.: Hypoglycemia in the newborn, a sequel of intrauterine malnutrition. Lancet, $i$ : 1282 (1963).

16. Reissner, S. N., Aranda, J. V., Colle, E., Papageorgiou, A., Schiff, D., Scriver, C. R., and Stern, L: The effect of intravenous glucagon on amino acids in the newborn. Pediat. Res., 7: 184 (1973).

17. Ruiton-Ugliengo, A., and Frederich, F.: Dosage radio-immunologique spécifique du glucagon pancréatique: Applications chez le nouveau-né et l'enfant. Diabète Métabol., 1: 143 (1975)

18. Salle. B., Chance, G. W., and Ruiton-Ugliengo, A.: In: J. Stetson and P. R. Swyer: Neonatal Intensive Care, p. 165 (Warren H. Green, St. Louis, Mo., $19(0)$.

19. Salle, B., and Ruiton-Ugliengo, A.: Glucose disappearance rate, insulin response and growth hormone response in the small for gestational age and premature infants of very low birth weight. Biol. Neonate, 29: 1 (1975).

20. Samols, J. K., Tyler, J. M., and Marks, V.: Glucagon-insulin interrelationships. In: P. J. Lefebvre and R. H. Unger: Glucagon, Vol. 151 (Pergamon Press, New York, 1972).

21. Sperling, M. A., Delamater, P. V., Phelps, D., Fiser, R. J. R., Oh, W., and Fischer, D. A.: Spontaneous and amino-acid stimulated glucagon secretion in the intermediate post-natal period: Relation to glucose and insulin. J. Clin. Invest. 53: 1159 (1974).

22. Unger, R. H.: Glucagon physiology and pathophysiology. N. Engl. J. Med., 285: 443 (197!).

23. Unger, R. H.: Alpha and beta cell interrelationships in health and disease. Metabolism, 23: 581 (1974).

24. Unger, R. H., and Lefebvre, P. J.: Glucagon physiology. In: P. J. Lefebvre and R. H. Unger, Glucagon, Vol. 47 (Pergamon Press, New York, 1972).

25. Williams, P. R., Fiser, R. H., Sperling, M. A., and Oh, W.: Effects of oral alanine feeding on blood glucose, plasma glucagon and insulin concentrations in small for gestational age infants. N. Engl. J. Med., 292: 612 (1975).

26. Wise, J. K., Lyall, S. S., Hendler, R., and Felig. P.: Evidence of stimulation for glucagon secretion by alanine in the human fetus at term. J. Clin. Endocrinol. Metabol., 37: 345 (1973).

27. Monsieur Biron, Départment d'Informatique, Hospices Civils de Lyon.

28. Informed consent was obtained from the parents so that their infants could be included in this study.

29. The authors wish to express their appreciation for advice and for the translation of Professor P. R. Swyer (Toronto), for the study of results of Professor Bertrand (Inserm, I.yon), for the technical help of Mrs F. Frederich and Mrs. Viand, and for the secretarial assistance of Miss M. Pastor.

30. The present address of Dr. A. Ruiton-Ugliengo is: Unité Inserm U.34 (Professor Bertrand) Hôpital Debrousse, 69005 Lyon (France)

31. Requests for reprints should be addressed to: B. L. Salle, M.D., Neonatal Department, Hôpital Edouard Herriot, 69374 Lyon Cedex 2 (France).

32. Received for publication March 2, 1976.

33. Accepted for publication August 6. 1976.
Calcitonin magnesium calcium parathyroid hormone growth skeletal tissues

\title{
Serum Calcitonin and Blood Mineral Interrelationships in Normal Children Aged Six to Twelve Years
}

\author{
RUTH SHAINKIN-KERSTENBAUM, BRURIA FUNKFNSTEIN, AVIVA CONFORTI, SHRAGA \\ SHANI, AND GEOFFREY M. BERLYNE (23) \\ Department of Nephrology and Toor Institute of Medical Research, Soroka University Hospital, Beersheba, Israel
}

\begin{abstract}
Summary
Simultaneous measurements of serum immunoreactive thyrocalcitonin (iTCT), immunoreactive parathyroid hormone (iPTH), calcium, inorganic phosphate, magnesium, and alkaline phosphatase were made in 37 normal children whose ages ranged from 6-12 years. Between the ages of 6 and 12 there is a
\end{abstract}

statistically significant rise in serum iTCT levels $(r=0.4638 ; P$ $<0.01)$, and a fall in serum iPTH levels $(r=0.4976 ; P<0.01)$. There is a highly significant inverse correlation between serum iTCT and iPTH levels $(r=0.5248 ; P<0.005)$. Serum iTCT levels were inversely correlated with phosphate levels $(r=$ $0.4989 ; P<0.01)$, the latter being age dependent and falling significantly between the ages of 6 and $12(r=0.4802 ; P<$ 